\title{
Improving estimations of maximal stand density by combining Reineke's size-density rule and the yield level, using the example of spruce (Picea abies (L.) Karst.) and European Beech (Fagus sylvatica $\mathbf{L}$.)
}

\author{
Jean-Philippe SchÜTZ*, Andreas ZINGG \\ WSL CH 8093 Birmensdorf, Switzerland
}

(Received 26 January 2009; accepted 17 September 2009)

Keywords:

Reineke /

maximal stand density /

yield level /

carrying capacity /

growth model /

mortality

\begin{abstract}
- The Reineke Stand density rule relating stem numbers to the quadratic mean diameter is generally used as a reference for modelling maximal stand density.

- The linearity of this relationship after double logarithmic transformation is generally assumed, but it must be questioned for untouched stands and stands with a conventional thinning regime. Curvilinearity is demonstrated for some spruce and beech stands in Switzerland and shown to be statistically representative. This relationship is independent of the site index. It can be interpreted as a change in mortality in young stages mainly due to competition and in older stages more to ageing.

- A more accurate estimation of the maximal stand density needs to take into account the important variation around the mean course, known as the yield level. A simple method to assess the yield level of any stand regardless of whether it is thinned or not is presented, based on estimating the effect of a stand opening on the basal area.
\end{abstract}

Mots-clés :

Reineke /

densité maximale /

niveau de production /

potentiel de production /

modèle de croissance /

mortalité naturelle
Résumé - Amélioration de l'estimation de la densité maximale de peuplement combinant la loi de taille-densité selon Reineke au niveau de production, à l'exemple de l'épicéa commun (Picea abies L. (Karst.)) et du hêtre (Fagus sylvatica L.).

- La loi de Reineke reliant le nombre de tiges au diamètre quadratique moyen est généralement utilisée comme référence pour la modélisation de la densité maximale de peuplements.

- On remet en question la linéarité d'une telle relation dans l'espace logarithmique, dans le cas des peuplements non traités aussi bien que pour ceux traités par des interventions conventionnelles. La curvilinéarité de cette relation est démontrée pour quelques peuplements purs d'épicéa et de hêtre en Suisse et dans sa représentativité statistique. La relation est indépendante de l'indice de fertilité et interprétée comme modification du type de mortalité au cours du développement, due pendant le jeune âge à la seule compétition, puis s'y ajoute celle due au vieillissement.

- Une estimation appropriée de la densité maximale des peuplements doit tenir compte des variations importantes autour de la courbe moyenne connue comme niveau de production. Une méthode simple de détermination du niveau de production dans tous les cas de traitement antérieur est présentée, fondée sur une estimation de l'effet de l'ouverture du couvert sur la surface terrière.

\section{INTRODUCTION}

The search for an objective and more or less invariant, but comprehensible, determination of stand density has preoccupied forest scientists for a long time. It belongs to conventional wisdom on forest yield to use therefore the so called stand density rule or self thinning rule of Reineke (Reineke, 1933), relying on the size to density relationship $N$ vs. $d_{g}$ (the quadratic mean diameter at breast height). Reineke considered

*Corresponding author: jph.s@bluewin.ch this rule to have a general character not only in forestry. Such an overall applicable size-density rule is, however, too simple to be biologically credible (Lonsdale, 1990). Its general application to different tree species has been repeatedly refuted (Lonsdale, 1990; Weller, 1987; White, 1981; Zeide, 1985) because each species, depending on its competitive tolerance, can exhibit other closure features. Even the applicability of the rule to the same tree species during stand development has been questioned because, in accordance with Zeide (1987): "Horizontal canopy closure of even-aged stands is in constant change; it is a process. The degree of horizontal crown 
closure is affected by two opposing and mutually related factors: lateral growth of crowns, which increases crown closure, and mortality, which decreases it." Thus the linearity of $N$ vs. $d_{g}$ in a double logarithmic grid has been questioned. Pretzsch (2006) presented results from long-term yield series from south Germany and demonstrated $\log (N)$ to $\log \left(d_{g}\right)$ relationship was, at least in some cases, non-linear.

One of the problems regarding the change in the steepness of the so called self-thinning line in the log grid leading to a convex curvilinear form is the question of a clear definition of what full stand closure is. In ageing stands, instability induced by long-term overcrowding leads to mortality, which originally affects only suppressed low social trees in juvenile stages (density-dependent mortality), affecting higher social elements from the adult stage on (active mortality due to hazardous events and ageing). It can result in changes in canopy closure which, if not excessive, are compensated for by the lateral growth of neighbouring trees. This phenomenon was the main reason, according to Zeide (1987), for the observed non-linearity of the self-thinning line for various tree species. Observations in virgin forests show that, at the end of a life cycle, a successive growing space release of the main stand occurs (Korpel, 1995). Thus, if the ontogenic cycle develops further, the main stand will collapse at any time. Yield research generally avoids this stage, in that, as soon as such a collapse occurs, and an opening or several openings appear, the record is interrupted. Thus long-term yield plot series represent only full closed stands. In reality, there is a continuous transition from full closure to light opening. In any case, an acceptable working hypothesis seems to be that, during the ontogenic development of the same tree species, the density relationships change successively.

Another question is whether the scale-density relationship for a particular species is dependent on the site index. Generalisation of Reineke's stand density rule implies more or less independency. Studies of Pinus radiata plantations (Bi, 2001) and other crops (Morris, 2003) provide evidence and suggest that the validity of this assertion should be doubted and, instead, that harsh site conditions influence competitiveness differently from good conditions.

When determining maximal stocking, another difficulty arises. The observed maximal basal area $G_{\max }$ varies within a large range, presenting sometimes extreme values beyond what is usually expected. This is particularly the case in countries with very different climatic conditions like in the perialpine zone, especially when precipitation attains a high level. For spruce stands, for instance, extreme maximal basal area value of more than $100 \mathrm{~m}^{2} /$ ha has been recorded (Bachofen and Zingg, 2001). The phenomenon that density and yield characteristics can vary substantially independently of the site index, was first mentioned 1955 by Assmann (1955) under the term "yield level". It was first defined as the variation in the total yield over $h_{q}$ (mean quadratic height), but the yield level also affects the maximal basal area $G_{\max }$ as well as the stem number density and other yield features (Assmann, 1974; Franz, 1965; 1967). Basal area can be considered as a good indicator of the carrying capacity of the site. Franz (1965) describes a different way to assess the yield level with a set of stand dendrometric variables, or alternatively as well with the $\mathrm{N}: d_{g}$ relationship. The latter is promising because it can be easily related to Reineke's way of assessing stand density. In fact, a scrutiny of a scatter plot of $\mathrm{N}: d_{g}$ values (Fig. 1) reveals a variation in both sides of the mean course. Reineke uses as a reference for the maximal stand density the outer line, tangential to the values of the scatter-plot. Albeit frequently used in this way (Zhang et al., 2005) this is questionable from a statistical as well as from a biological point of view, because it is based on the assumption that only extremes values represent the real maximum stocking. In reality, every value represents full closure. The variation in the stand density can be more than trivial. For beech and spruce stands under Swiss conditions it amounts to about $80 \%( \pm 40 \%$ of the mean value) (Schütz, 2008). Other authors demonstrated similar significant variation (Assmann, 1974; Bégin and Schütz, 1994; Franz, 1965; 1967; Kennel, 1973; Pfadenauer, 1975) depending on site conditions not yet entirely explained until now. Reinecke way of assessing density leads to overestimate the real density conditions by half of the variation around the mean. Thus the self-thinning curve should correspond to the statistical mean course of $\ln (N): \ln \left(d_{g}\right)$. In this case, it may be interesting to consider the residual variation, i.e. the quotient $N_{\text {observed }}$ to $N_{\text {mean }}$, as the yield level.

Stand density relationships are strictly considered valid only when derived from untouched stands. In temperate central Europe, with a tradition of repeated thinning untouched stands do not represent normality and untouched yield plots are rare. Overcrowding tends to increase their instability and, especially for species vulnerable to storms like spruce (Schütz et al., 2006), threatens their survival. Nevertheless, allometric relationship during ontogenic development of the stands could also be verified in treated forests stands under the condition that the thinning regime is uniform. On the other hand, a thinned stand provides the advantage that thinning avoids mortality from overcrowding and ensures more stability in the upper storey of the stand. Since 1882 (i.e. since foundation of the IUFRO), West European yield research has harmonized the definition of thinning especially for the implementation of yield trial series (Verein Deutscher Forstlicher Versuchsanstalten, 1902). Thus, especially in Germany and Switzerland, long yield time series have been recorded under the same thinning regime, B (moderate thinning from below) up to today, which fulfils the above mentioned conditions of uniformity of the thinning regime. B-plots are functionally not very different from plots in untouched stands as the thinning does not interfere significantly with the main stand development. In Switzerland since the 1930s, when Schädelin (Schädelin, 1934) proposed selective thinning ( $\mathrm{H}$ according to IUFRO definition), this thinning regime has been applied throughout the country so that we also have long series for this regime, and they should also be scrutinised.

The determination of the yield level in repeatedly thinned stands with different regimes is more difficult because of compensative forces between the removed trees and the canopy closure due to the lateral expansion of the crown. In practice, the silvicultural history of the stands is normally not known, at least not in detail. The basal area contains intrinsically the 
yield level and appears to be the right indicator for its determination. The problem is that basal area also depends on the thinning history. Assmann (1957) showed, on the basis of thinning trials with very different thinning intensities, that full compensation occurs within some limits of closure opening, from full closure to a thinning intensity threshold (rule of the relative mean basal area). Only below the threshold of the so called critical basal area $G_{\text {crit }}$ does a clear reduction in the yield features (increment) occur. In finding a way to assess the influence on the basal area $G$ of the reduced stand density i.e. by thinning it appears possible to separate the two influences mentioned above and as a result to determine correctly the yield level, for all plots treated and not treated. This allows enlarging the data base and enhances performing statistic regressions.

The aim of the present work is to verify and quantify the size-density relationship so to be able to predict the maximal basal area $G_{\max }$ including its variation (yield level). The variables included should be as simple as possible so that the method can be used for practical purposes. The study was part of a project to construct a modern, distance independent, growth simulator for even-aged pure spruce (Picea abies Karst.) and beech (Fagus sylvatica L.) stands in Switzerland (Model SiWaWA), based on one of the largest data set from classical yield plots available as well as on several onetime surveys. Because there are not sufficient complete time series of untouched stands, the data base was enlarged with a set of incomplete series and some temporary plots. These were carefully selected for representativeness according to site variation and stand closure. Some plots from primeval forest from Switzerland and for spruce from Slovakia have also been added in order to cover the mature development stages that are normally missing in yield series, as long as they correspond to yield plots regarding tree species composition (pure stands) and stand closure conditions (only stands with full closure).

\section{MATERIALS AND METHODS}

The data was taken mainly from permanent yield plots repeatedly measured over a long time span (1882-2006), mostly from the yield data base WSL (Swiss Federal Institute for Forest Snow and Landscape Research, Birmensdorf). The permanent yield plots WSL are distributed over the whole of Switzerland. Plots above $1200 \mathrm{~m}$ a.s.l. have been excluded. Plot size generally amounts to about 0.25 ha. All trees are identified by a number. Measurements were carried out about every 4 to $7 \mathrm{y}$ after a thinning intervention. The dbh of all trees above $4 \mathrm{~cm}$ dbh (in some case for young stands above $2 \mathrm{~cm}$ ) is accurately recorded to $\mathrm{mm}$, crosswise with a calliper. Inventories from the plots of the chair of silviculture ETH-Z have been added to enlarge the information base on untreated stands and also to keep records of the actual kinds of treatment of selective thinning according to Schädelin (1934) particularly in the old and mature stages. ETH plots are of two kinds: (1) repeated surveys, similar to the WSL plots in design and measurement, regarding one thinning trial with three intensities of selection thinning in spruce (regime $\mathrm{H}$ ) and four permanents plots in a pure beech pristine forest reserve St-Ursanne (Tariche) in Switzerland; (2) selected stands, surveyed once, from the training forest ETH, typical for the treatment $\mathrm{H}$ but with full canopy closure, as well as 51 plots of untreated stands, selected for a Ph.D.-thesis (Ammann, 2004). To obtain more information on older development stages for untreated spruce, which is very important for verifying the extremities in the $N: d_{g}$ thinning curve, three inventories of a permanent plot from the virgin forest Kosodrevina (Chopok) Low Tatras, Slovakia (elevation 1230 ) have been included, selected from a development stage with full closure (see diameter distribution of the plot 3 in Korpel, 1995, p. 252). This is the only comparable spruce virgin forest available. Other spruce Slovakian virgin forests lie in the near subalpine belt and could not be considered according to Korpel (1995), because they showed differences between mountain and subalpine forest dynamics at an altitude threshold of about $1500 \mathrm{~m}$ a.s.1.

Thinning interventions in WSL plots correspond, in terms of thinning types and intensity, generally to conventional practice, i.e. with moderate thinning from below until about 1940 i.e. grade B according to IUFRO rules (Verein Deutsche Forstlicher Versuchsanstalten, 1902) and selective thinning according to Schädelin (1934) after 1940. In some cases yield series with variation in thinning intensity ( $\mathrm{A}=$ natural thinning, $\mathrm{B}=$ moderate thinning from below, $\mathrm{C}=$ heavy thinning form below, $\mathrm{D}=$ very heavy thinning from below, $\mathrm{H}=$ thinning from above) have been established.

The complete data set available consists of 418 surveys for spruce and 620 for beech. Table I presents the distribution between complete long times series (30\% of the surveys for spruce and $45 \%$ for beech), incomplete long time series $(29,29 \%)$, short time series with 2 to 5 surveys $(21,23 \%)$ and one time surveys $(19,3 \%)$. Table II presents the age class distribution of the surveys, showing a lack of data for unthinned older spruce stands, and, but less evident, on unthinned beech stands. This explains the necessity to incorporate data from pristine forests. The variation in terms of site index defined as the top height at age $50 \mathrm{y}$ is $15.5-30.7 \mathrm{~m}$ for spruce and $12-26 \mathrm{~m}$ for beech, and in terms of stand density (SDI) $0.403-1.000$.

The heights of a sample of 20 to 40 trees at each site were measured with a hypsometer type Jal with a $7 \mathrm{~m}$ reference rod and an accuracy of about $0.8 \mathrm{~m}$. The site-index, defined as the top height (mean height of the 100 largest trees per ha) at the age of $50 \mathrm{y}\left(H_{\mathrm{dom}} 50\right)$ is determined with the height:age function of the growth simulator SiWaWa.

Different models have been tested to explain $N$ (stem numbers) as dependent from the mean quadratic diameter $d_{g}$ and its square to assess curvilinearity in model (1) as well as the addition of the covariables Site Index (SI) (model 2) and the provisional stand density (PDI) model (3). PDI is the quotient between $N_{\text {observed }}$ and $N_{\text {function(1) }}$ in the model and corresponds to the factor SDI (site density index) in Reineke's terminology sensu. In the latter case, the density is related to the outer line tangent of the value scatter-plot. In the former case it is related to the mean curve position. This explains the need for a different terminology.

$$
\begin{gathered}
\ln \left(N_{\max }\right)=\alpha+\beta \times \ln \left(d_{g}\right)+\gamma \times\left[\ln \left(d_{g}\right)\right]^{2}+\varepsilon \\
\ln \left(N_{\max }\right)=\alpha+\beta \times \ln \left(d_{g}\right)+\gamma \times\left[\ln \left(d_{g}\right)\right]^{2}+\delta \times S I+\varepsilon \\
\ln \left(N_{\max }\right)=\alpha+\beta \times \ln \left(d_{g}\right)+\gamma \times\left[\ln \left(d_{g}\right)\right]^{2}+\delta \times S I+\varphi \times P D I+\varepsilon .
\end{gathered}
$$

Regression analysis was processed with the statistics package SYSTAT for windows (Systat software Inc.). The distribution of the residues was controlled visually and found to be appropriate in every case. 
Table I. Characteristics of the data material, distribution between different yield series and not permanent surveys, for the different thinning regimes.

\begin{tabular}{|c|c|c|c|c|c|c|c|c|c|c|}
\hline \multirow{2}{*}{ Type of survey } & \multicolumn{2}{|c|}{ Thinning regime $\mathrm{A}$} & \multicolumn{2}{|c|}{$\overline{\mathrm{B}}$} & \multicolumn{2}{|c|}{$\mathrm{C}$} & \multicolumn{2}{|c|}{$\mathrm{D}$} & \multicolumn{2}{|c|}{$\mathrm{H}$} \\
\hline & $N_{s}$ & $N_{i}$ & $N_{s}$ & $N_{i}$ & $N_{s}$ & $N_{i}$ & $N_{s}$ & $N_{i}$ & $N_{s}$ & $N_{i}$ \\
\hline \multicolumn{11}{|l|}{ Spruce } \\
\hline Complete long time series $^{a}$ & 3 & 27 & 4 & 29 & 3 & 25 & 3 & 20 & 3 & 23 \\
\hline Incomplete time series ${ }^{b}$ & & & 7 & 62 & 5 & 35 & 1 & 10 & 2 & 15 \\
\hline Short time series ${ }^{c}$ & 8 & 21 & 13 & 44 & 3 & 8 & 1 & 1 & 5 & 16 \\
\hline One time plot & 45 & 45 & 3 & 3 & 1 & 1 & & & 29 & \\
\hline Slovakia, permanent $t$ plots & 1 & 4 & & & & & & & & \\
\hline Sum & 57 & 97 & 27 & 138 & 12 & 69 & 5 & 31 & 39 & 83 \\
\hline \multicolumn{11}{|l|}{ Beech } \\
\hline Complete long time series & 3 & 26 & 5 & 62 & 6 & 76 & 3 & 38 & 6 & 75 \\
\hline Incomplete time series & & & 17 & 169 & & & & & 1 & 14 \\
\hline Short time series & $4^{d}$ & 12 & 26 & 73 & 7 & 30 & 2 & 8 & 5 & 18 \\
\hline One time plot & 6 & 6 & & & & & & & 13 & 13 \\
\hline Sum & 13 & 44 & 48 & 304 & 13 & 106 & 5 & 46 & 25 & 120 \\
\hline
\end{tabular}

Thinning regime according to the IUFRO definition and [41]: $\mathrm{A}=$ natural thinning; $\mathrm{B}=$ moderate thinning from below, $\mathrm{C}=$ heavy thinning from below; $\mathrm{D}=$ very heavy thinning from below, $\mathrm{H}=$ selective thinning from above. $\mathrm{Ns}=$ Number of sites; $\mathrm{Ni}=\mathrm{Number}$ of surveys.

${ }^{a}$ Long time series in the same stand, more than 5 repeated surveys.

${ }^{b}$ Diachronic time series at the same site.

${ }^{c}$ Short time series, $2-5$ repeated surveys.

${ }^{d}$ From the reserve St-Ursanne Switzerland.

Table II. Age structure of the data material; number of surveys for the different thinning regimes.

\begin{tabular}{|c|c|c|c|c|c|c|c|c|c|c|}
\hline \multirow[b]{2}{*}{ Thinning regime } & \multicolumn{5}{|c|}{ Spruce } & \multicolumn{5}{|c|}{ Beech } \\
\hline & $\mathrm{A}^{*}$ & $\bar{B}$ & $\mathrm{C}$ & $\overline{\mathrm{D}}$ & $\mathrm{H}$ & $\mathrm{A}^{*}$ & $\mathrm{~B}$ & $\mathrm{C}$ & $\bar{D}$ & $\mathrm{H}$ \\
\hline $10-19$ & 4 & & & & & 1 & & & & \\
\hline $20-29$ & 18 & 4 & 2 & 1 & 10 & 3 & 4 & 8 & 2 & 3 \\
\hline $30-39$ & 29 & 16 & 11 & 3 & 12 & 4 & 19 & 8 & 5 & 15 \\
\hline $40-49$ & 14 & 21 & 22 & 6 & 10 & 6 & 31 & 10 & 5 & 9 \\
\hline $50-59$ & 22 & 20 & 17 & 8 & 12 & 6 & 35 & 8 & 7 & 11 \\
\hline $60-69$ & 7 & 23 & 11 & 7 & 15 & 4 & 32 & 10 & 6 & 13 \\
\hline $70-79$ & 2 & 17 & 5 & 4 & 8 & 2 & 34 & 14 & 5 & 17 \\
\hline $80-89$ & 2 & 11 & 2 & 2 & 8 & 3 & 30 & 13 & 6 & 13 \\
\hline $90-99$ & & 10 & & & 6 & 1 & 30 & 9 & 5 & 13 \\
\hline $100-109$ & & 10 & & & 2 & 1 & 23 & 9 & 3 & 7 \\
\hline $110-119$ & & 3 & & & 1 & 1 & 19 & 8 & 3 & 6 \\
\hline $120-129$ & & 5 & & & & & 21 & 5 & 2 & 6 \\
\hline $130-139$ & & 1 & & & & & 15 & 2 & 2 & 5 \\
\hline $140-149$ & & & & & & & 4 & 2 & & 2 \\
\hline $150-159$ & & & & & & & 3 & & & \\
\hline $160-169$ & & & & & & & 3 & & & \\
\hline $170-179$ & & & & & & & 1 & & & \\
\hline $180-189$ & & & & & & & 1 & & & \\
\hline
\end{tabular}

* Excluding the virgin forest in Slovakia (spruce) and the reserve St-Ursanne (beech).

\section{RESULTS}

Figure 1 shows the classical size-density relationship stem numbers $(N)$ over $d_{g}$, according to Reineke (1933) for unthinned stands in a double logarithmic grid for spruce and beech. The mean curve is fitted with multiple regression analysis. In order to test the curvilinearity, a quadratic term is included following Pretzsch (2006), model (1).
The results of the regression analysis are expressed in terms of the $t$-statistic of the standard partial regression coefficient tolerance of the variables, representative of their usefulness in the model and the corresponding p-tail of the transgressionprobability (Tab. III). Significant parameters are highlighted in bold. A statistically significant parameter $\gamma$ means that the curvilinearity of the model applies.

This means that the inclusion of the quadratic component is highly significant. 


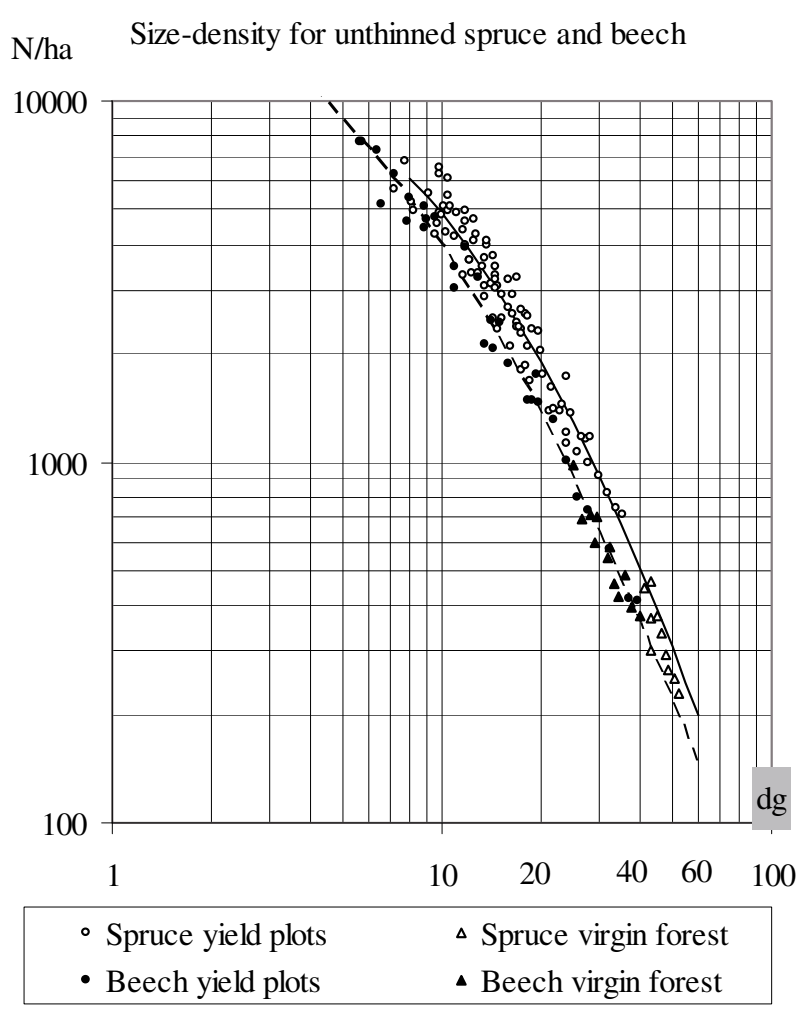

Figure 1. $\ln \left(N_{\max }\right)$ over $\ln \left(d_{g}\right)$ for untouched beech stands and spruce stands.

Figures $2 a-2 c$ shows the size-density relationship for different thinning regimes $\mathrm{H}$ (selective thinning from above), B (moderate thinning from below), $\mathrm{C}$ (heavy thinning from below) and $\mathrm{D}$ (very heavy thinning from below) for beech stands. Figure 3 depicts the same for spruce stands, but only displaying single values for $\mathrm{H}$-thinning. The corresponding $t$-statistic for the standard coefficient tolerance for the different variables is given in Table IV.

In order to verify a possible influence of the site index (SI) on the size density relationship, a multiple regression is fitted with the site index (SI) as an additional dependent variable (Eq. (2)) for the unthinned stands. The site index is defined as the top height $\left(h_{\mathrm{dom}}\right)$ of trees aged $50 \mathrm{y}$. The corresponding $t$ statistic for the standard coefficient tolerance of the variables is given in Table $\mathrm{V}$.

In both cases the influence of the site index appears not to be significant with a $p$-tail of $34 \%$ and $20 \%$. Because of the relatively small number of different values in the data set for unthinned stands, an eventual influence of the site index is verified with all plots, including the treated stands by incorporating the stand density and the variable PDI (provisional density index) into the regression (model 3).

The $t$-statistic of the standard coefficient tolerance in model (3) shows that the parameter $\delta$ caracterising the effectiveness of the site index is not significant, with $\mathrm{t}$ values for spruce: $t=1.23(p=0.2179$ n.s. $) N=315 ; R^{2}=0.998$ and for beech $t=0.77$ ( $p=0.4401$ n.s.) $N=661 ; R^{2}=0.998$. Otherwise the parameters $\gamma$ and $\phi$ are highly significant. This
Table III. $t$-statistics for model (1).

\begin{tabular}{lccc}
\hline Parameter & $\alpha$ & $\beta$ & $\gamma$ \\
\hline Spruce & & & \\
Standard coefficient tolerance & & 1.28 & $\mathbf{- 4 . 3 3}$ \\
Corresponding probability & & 0.20 & 0.0000 \\
Parameter value & 9.0145 & 0.647461 & -0.3801 \\
$N$ & 88 & & \\
$R^{2}$ & 0.940 & & \\
\hline Beech & & & \\
Standard coefficient tolerance & & -0.38 & $\mathbf{5 . 6 7}$ \\
Corresponding probability & & 0.703 & 0.0000 \\
Parameter value & 9.9648 & -0.1006 & -0.2731 \\
$N$ & 44 & & \\
$R^{2}$ & 0.988 & & \\
\hline
\end{tabular}

corroborates evidently the results of model (2). It is worth mentioning in this model (3) that $N$ is not equal $N_{\max }$.

\section{Separation of the influence of yield level and stand closure for treated stands}

In the case of unthinned stands the basal area is therefore a very adequate indicator for the stand density. It is functionally directly dependent on $N$ and $d_{g}$, intrinsically as a product of $N$ and $d_{g}$ square. However, density is not identical with canopy closure, as full closure can occur at very different basal areas, depending on the yield level. For instance, for adult spruce stands, full canopy closure is reached with basal area varying from about $50 \mathrm{~m}^{2}$ up to $74 \mathrm{~m}^{2}$ where the stand characteristics are the same (site index and age) due to differences in the yield level, in this case from 0.8 to 1.2 , which is absolutely realistic (Fig. 4).

In thinned plots with unknown thinning history, the determination of the yield level is more difficult because thinning affects the basal area. A realistic determination of the yield level can be assessed if we can determine the portion of basal area $G$ due to the thinning regime $\left(\Delta G_{\text {th }}\right)$. This has been performed on data of plots with a known thinning regime. An estimation of the effect of the thinning regime on the basal area $G$ has been assessed with the difference between the mean basal area of all plots (unthinned and thinned) to the mean basal area $G$ corresponding to the thinning regime under examination. Thus $\Delta G_{\mathrm{th}}+G_{\text {observed }}=$ putative $G_{\max }$. Figures $5 \mathrm{a}$ and $5 \mathrm{~b}$ shows the $\Delta G_{\text {th }}$ values over the density expressed with PDI for spruce and beech.

This relationship can be fitted with the following model.

$\Delta G_{\text {th }}=\alpha+\beta \times P D I^{-2}+\gamma \times\left(20-d_{q}\right)^{2}+\varepsilon$ (4a for spruce)

$\Delta G_{\mathrm{th}}=\alpha+\beta \times P D I^{-1.2}+\gamma \times\left(40-d_{q}\right)^{2}+\varepsilon .(4 \mathrm{~b}$ for beech $)$

The power coefficient has been determined iteratively, and the culmination of a quadratic influence of $d_{g}$ visually. The corresponding t-statistic for the standard coefficient tolerance for the different variables is given in Table VI.

Thus, for each plot, regardless of its thinning history, the yield level can be estimated as following:

$$
E N=\left(\Delta G+G_{\text {observed }}\right) / G_{\text {mean untreated }} .
$$


(a)

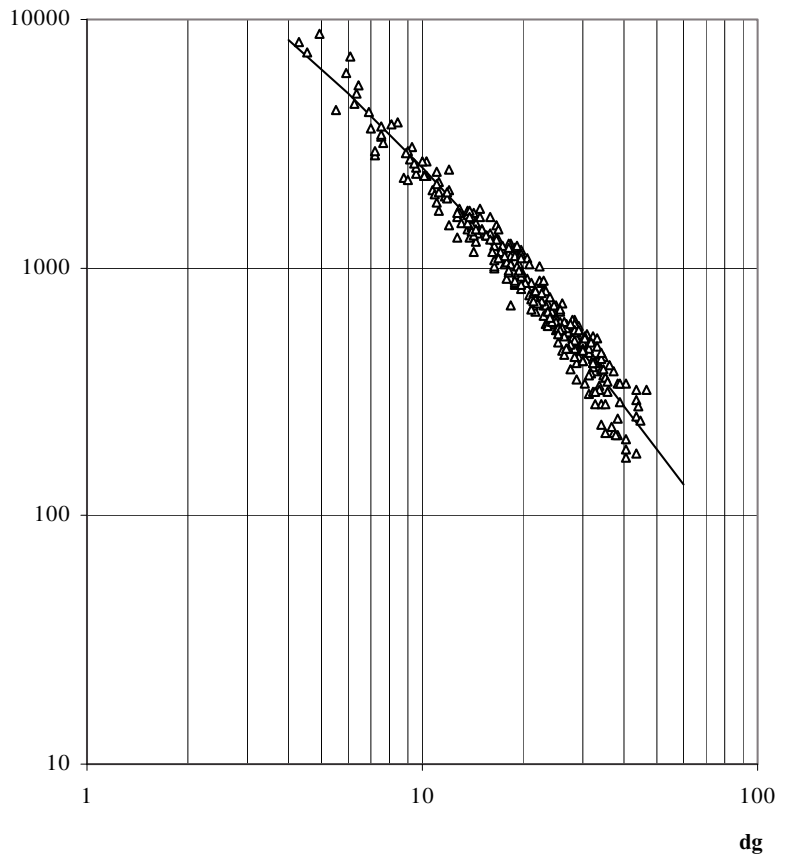

(b) Beech, $\mathrm{N}: \mathrm{dg}$ for treated stands, thinning regime $\mathrm{C}$

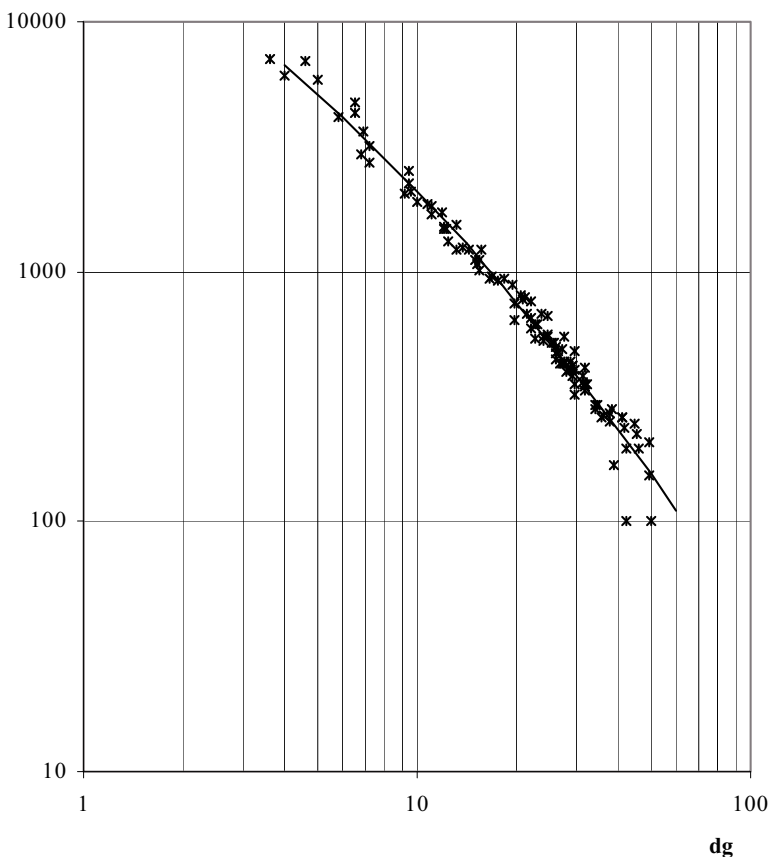

(c) Beech, N: $d_{g}$ for treated stands, thinning regime D

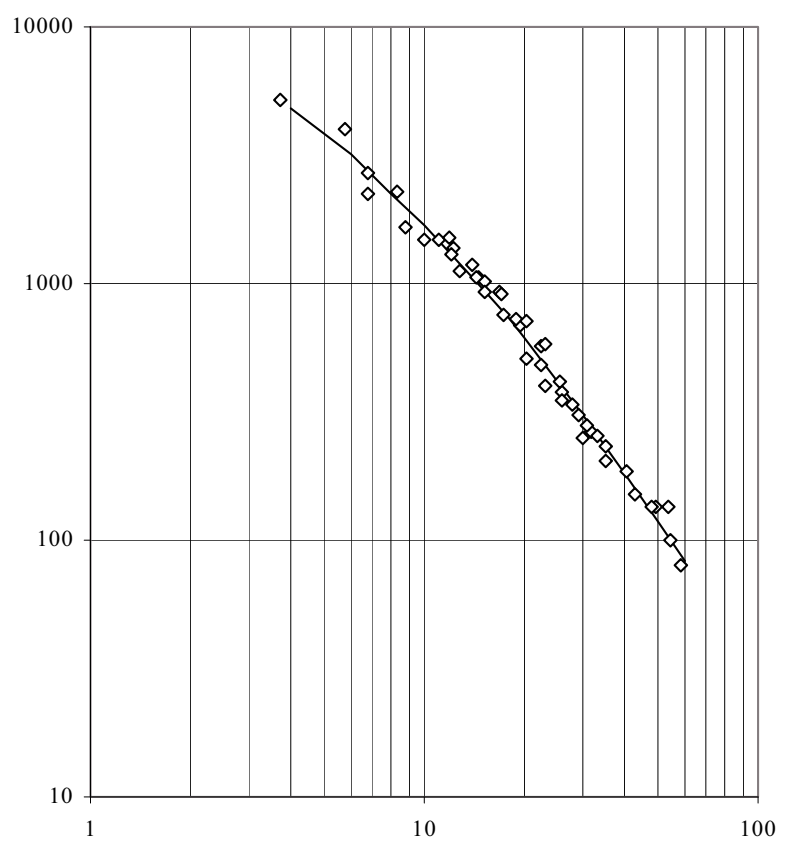

Figure 2. $\ln (N)$ over $\ln \left(d_{q}\right)$ for treated beech stands with known thinning regimes; (a) thinning regime B, moderate thinning from below; (b) thinning regime $\mathrm{C}$, heavy thinning from below; (c) thinning regime $\mathrm{H}$, selective thinning from above; according to IUFRO rules. 
Table IV. $t$-statistics for model (1) and different thinning regimes. Significant standard coefficient tolerance are expressed bold.

\begin{tabular}{lcccc}
\hline Thinning regime & $\mathrm{H}$ & $\mathrm{B}$ & $\mathrm{C}$ & $\mathrm{D}$ \\
\hline Spruce & & & & \\
Parameter $\beta$ & & & & \\
Standard coefficient tolerance & $\mathbf{2 . 5 6}$ & $\mathbf{5 . 5 6}$ & $\mathbf{4 . 4 5}$ & $\mathbf{2 . 2 8}$ \\
Corresponding probability & 0.0116 & 0.0000 & 0.0000 & 0.0270 \\
Parameter $\gamma$ & & & & \\
Standard coefficient tolerance & $\mathbf{- 7 . 6 3}$ & $\mathbf{- 4 . 7 4}$ & $\mathbf{- 4 . 1 7}$ & $\mathbf{5 . 9 4}$ \\
Corresponding probability & 0.0000 & 0.0000 & 0.0000 & 0.0000 \\
$N$ & 120 & 305 & 106 & 46 \\
$R^{2}$ & 0.980 & 0.961 & 0.978 & 0.987 \\
\hline Beech & & & & \\
Parameter $\beta$ & 1.28 & $\mathbf{3 . 1 7}$ & $\mathbf{3 . 4 9}$ & 0.62 \\
Standard coefficient tolerance & 0.0200 & 0.0000 & 0.0008 & 0.5300 \\
Corresponding probability & & & & \\
Parameter $\gamma$ & $\mathbf{4 . 3 3}$ & $\mathbf{- 4 . 8 7}$ & -0.37 & $\mathbf{- 2 . 9 5}$ \\
Standard coefficient tolerance & 0.0000 & 0.0000 & 0.7000 & 0.0070 \\
Corresponding probability & 88 & 78 & 70 & 25 \\
$N$ & 0.940 & 0.951 & 0.968 & 0.986 \\
$R^{2}$ & & & & \\
\hline & & & \\
\hline
\end{tabular}

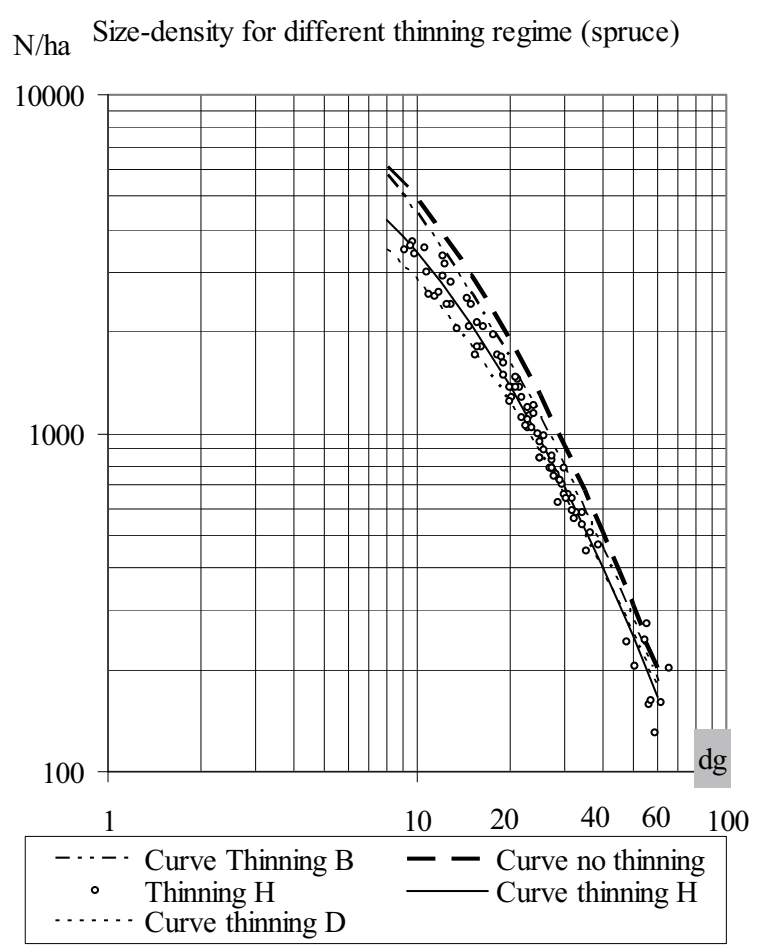

Figure 3. $\ln (N)$ over $\ln \left(d_{g}\right)$ for treated spruce stands with known thinning regimes.

\section{DISCUSSION}

It is not our intention to discuss the generality of the socalled 2/3 power rule of Yoda et al. (1963) and its applicability to every plant crop, as this has been critically discussed numerous times. However, our results seem to support criticism of the universality of this rule (see Pretzsch, 2000; 2005).
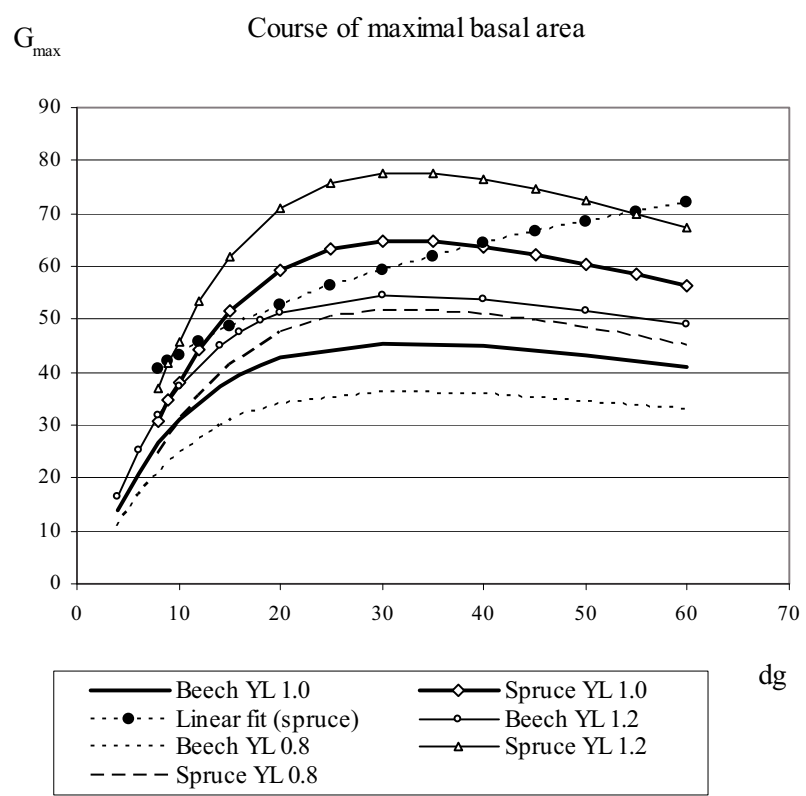

Figure 4. Course of the maximal basal area for spruce and beech, with variations due to the yield level of 0.8 and 1.2 respectively. For spruce, it displays the course derived from a linear $\ln (N)$ to $\ln \left(d_{g}\right)$.

Our data material applies to the classical yield of two important tree species in temperate European forestry. Under discussion here is the particular applicability of Reineke's standdensity rule (Reineke, 1933), determined as the $\ln (N)$ to $\ln \left(d_{g}\right)$ relationship. It is usually accepted that this relationship is invariant during the ontogenic development, but it may also be variable.

The curvilinearity of the relationship $\ln (N)$ to $\ln \left(d_{g}\right)$ turns out to apply, at least to the data and statistics recorder in Switzerland. Thus it seems justified to use equation (1) as the 
Table V. $t$-statistics for model (2).

\begin{tabular}{lccc}
\hline Parameter & $\beta$ & $\gamma$ & $\delta$ \\
\hline Spruce & & & \\
Standard coefficient tolerance & 1.06 & $\mathbf{- 3 . 3 8}$ & 0.95 \\
Corresponding probability & 0.291 & 0.0011 & 0.3450 \\
$N$ & 82 & & \\
$R^{2}$ & 0.924 & & \\
\hline Beech & & & \\
Standard coefficient tolerance & 0.70 & $\mathbf{- 6 . 9 1}$ & 1.31 \\
Corresponding probability & 0.4862 & 0.0000 & 0.1976 \\
$N$ & 50 & & \\
$R^{2}$ & 0.986 & & \\
\hline
\end{tabular}

Table VI. $t$-statistics for model (4 a and b).

\begin{tabular}{lccc}
\hline Parameter & $\alpha$ & $\beta$ & $\gamma$ \\
\hline Spruce & & $\mathbf{1 5 . 1 5}$ & 1.92 \\
Standard coefficient tolerance & & 0.0000 & 0.0507 \\
Corresponding probability & & 11.9895 & 0.003572 \\
Parameter value & -8.1995 & & \\
$N$ & 317 & & \\
$R^{2}$ & 0.436 & & \\
\hline Beech & & $\mathbf{2 2 . 5 8}$ & $\mathbf{- 1 3 . 9 0}$ \\
Standard coefficient tolerance & & 0.0000 & 0.0000 \\
Corresponding probability & & & \\
Parameter value & -13.1349 & 14.9313 & -0.005849 \\
$N$ & 621 & & \\
$R^{2}$ & 0.510 & & \\
\hline
\end{tabular}

reference to determine the normal stand density of a growth simulator. The data base appears to be sufficient and representative enough for this. Particularly convincing is that the convex course of the relationship and the form of the deflection which is comparable throughout the different thinning regimes and for the two species. These results contradict previous findings that Reineke's thinning curve is linear and invariant (Enquist and Niklas, 2001; Lonsdale, 1990; Weller, 1987; Zeide, 1987; 2005). Whether a change in the steepness of the relationship during the ontogenic development can be interpreted as a change in allometry as suggested by Zeide (1987), is herewith not definitively verified, because we cannot exclude that canopy gaps, even if they are very small and dispersed, had occurred anytime, but they suggest that changes in closure behaviour occurs. Our data from permanent yield plots represent principally full closure conditions, as stands were excluded if the canopy is interrupted. The same applies to the one-time plots, selected after carefully verification of their representativeness and their full closure, and especially to those from unthinned stands after verification of their former history.

There are two methodological sources of bias to be discussed. Firstly, for very young stands, $d_{g}$ corresponds to the full, and not to the truncated distribution of the trees due to an inventory threshold. Our data were verified on the basis of diameter distributions and, if necessary (in the case of truncated distributions), excluded from the calculations. Thus $N$ should consider the entire cohort, but without second growth, under
$\Delta \mathrm{G}_{\mathrm{th}}$

$\Delta \mathrm{G}_{\mathrm{th}}$ vs. PDI (Spruce)
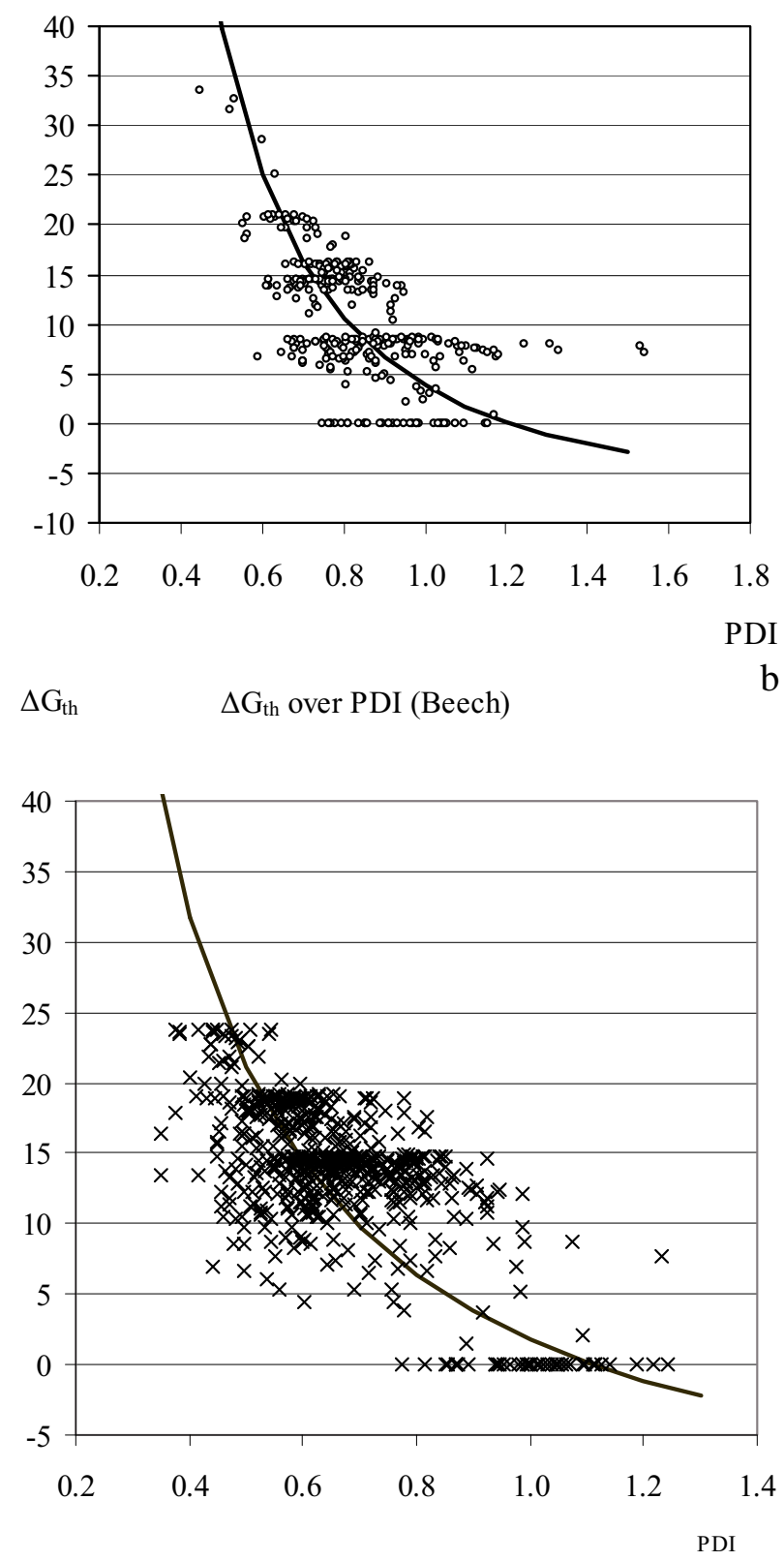

Figure 5. Proportion of the basal area due to thinning effect $\left(\Delta G_{\max }\right)$, i.e. $G$ difference between curve of the thinning regime and no thinning in relation to stand density (provisional density index PDI) for spruce and beech.

storey or brushwood. Nevertheless, the convexity of the thinning curve appears particularly clear for the smaller diameters, maybe because mortality due to overcrowding manifests itself only after a certain period of tightness. This would be the case for a stand with planting with large spacing but does not apply to our data that developed from dense plantations or natural regeneration. It is possible that there is a certain delay in the self thinning process or that very young trees are more resilient to 
overcrowding. Franz (1965) studied the yield level of spruce in Bavaria and claimed that young stands (under $40 \mathrm{y}$ ) should not be considered in calculating yield level because it had not yet reached an equilibrium. In our case, this is not that relevant for modelling the stand density because transformation of $N$ and $d_{g}$ into basal area in the case of very young stands does not affect substantially the level of basal area $G$ (see Fig. 4).

A second methodological source of bias is related to the logarithmic transformation method regularly used to display the self thinning course and to calculate the corresponding regression coefficients. Logarithmic transformation introduces an important weighting of the values favouring the small over the larger dimensions. As a matter of principle, this can be taken into account by weighting the values inversely proportional to the logarithm. We did not weight our data that it can be compared with literature. This kind of bias is more important. Values for large $d_{g}$ are more often underrepresented because the observations are interrupted following stand decay or even intentional regeneration. Maintaining full closure should not be considered as static as it usually is, but a dynamic process leading normally to progressive canopy opening. That was a reason for us to verify thoroughly the full closure conditions, and to incorporate data from primeval (virgin) forest research plots displaying full closure.

Pretzsch (2005b) considers it necessary to check whether the thinning curve is linear, case by case on long time series (chronosequences) for the same stand. He found that 2 out of 9 long time series were curvilinear for spruce and 3 out of 9 for beech. We agree principally with this argument, although the problem of the definition of real closure conditions and successive canopy opening remains the same as for scatter plots. We have only a few time series at our disposal and only a few repeated observations (mean 6.4 spruce and 8.4 for beech). For spruce particularly very old values are lacking. Therefore, Pretzsch's approach is not quite appropriate for our data. Nevertheless, we calculated for all chronosequences with more than 5 inventories the regression according to equation (1) including A (natural thinning) and B plots (moderate thinning from below). At a level of transgression probability of $5 \%$ it appears that $1 / 3$ for spruce A-plots, $1 / 10$ of spruce B-plots, 2/3 of beech A-plots and 6/14 of beech B-plots have significantly negative $\gamma$. No positive $\gamma$ was found, in contrast to Pretzsch (2005).

Figure 4 also shows the substantial consequences of using a curvilinear fitting of the $N: d_{g}$ curve in comparison to the classical linear fitting. In terms of basal area, the difference is impressive, especially over $d_{g} 40$.

In conclusion, in some cases there is evidence of a convex curvilinear thinning curve, especially in beech. When considering a large distribution of plots, it appears as a clear tendency. Because mortality due to hazards is largely, although not absolutely, excluded from our material the phenomenon could be due to changes in canopy utilization. A possible explanation is that mortality due to overcrowding, affecting social low elements in young stands, changes with time, affecting more elements of the main canopy in adult stages and especially ageing stages. Pretzsch $(2006 ; 2008)$ presents results for spruce and suggests as a factor retraction of the crown due to swaying movements as well as the geometry of space occupancy and other factors.

Differences between the spruce and beech stands were substantial, paticularly the level of basal area $G$. The stocking of full closed beech stands culminate at approx. $45 \mathrm{~m}^{2}$ in comparison with approx. $65 \mathrm{~m}^{2}$ for spruce (see Fig. 4), i.e. about 50\% more for spruce. This corroborates the differences in growth efficiency found by Pretzsch and Schütze (2005) who found a better space occupancy of spruce and a better space exploitation of beech due to differences in branching and resource allocation. The lightly more convex form of the $G$-course for beech corresponds to a greater change in $N: d_{g}$ steepness of the thinning curve, as well as the more lateral expansion of the beech crown.

One of the valuable results is the independence of the sizedensity and the site index. A first visual analysis of the distribution of $N: d_{g}$ values from different site index classes (not shown here) revealed no pattern supporting such an effect. The statistical analysis through regressions analysis confirms this. The range of site index varies between 15.5 and $30.7 \mathrm{~m} h_{\mathrm{dom}}$ for trees aged 50 for spruce and between 12.0 and $26.0 \mathrm{~m}$ for beech which is rather a wide range. It seems that height differences as encapsulated in the site index explain the space occupancy behaviour sufficiently.

One of the interesting results is that the classical way of assessing the productivity of a site with the site index based on the height:age relationship does not influence particularly the size density relationships. On the other hand, the basal area $G$ varies substantially, give reasons to reconsider the validity of the site index utilization. For regions with a great site variation (climate, precipitation, soil, aspect), where substantial variation of yield level could be expected, the basal area $G$ is much more appropriate to characterize the yield performances than age to height. This is illustrated in Figure 4 where the range of variation in basal area $G$ is much wider between the low and the high yield level than variations in stand development $\left(d_{g}\right.$ or age). This does not mean that the site index, which gives the third dimension (stand height), is not useful. To determine all three dimensional variables like volume, the site index is determinant. Thus we need to determine two components of the yield capacity: its horizontal dimension expressed by the yield level and its vertical by the site index. In our study the former revealed more influential than the latter. The growth simulator SiWaWa, for instance, is elaborated on the assumption that basal area $G$ and mean quadratic diameter are sufficient as primary entry variables in the model. It is not necessary to determine the site index with high precision. Its estimation with floristic maps or broad geographic and climatic variables is sufficient (Keller, 1978). Even age is not considered as a primary variable, as the stand development can be easily characterized by $d_{g}$, with age derived indirectly. This simplifies the practical application because age is often not known and height is difficult to assess. This approach complies with in the spirit of Langton's think movement/theory of so called artificial life (Langton, 1989), which aims to explain a complex system with criteria that are as simple as possible. 


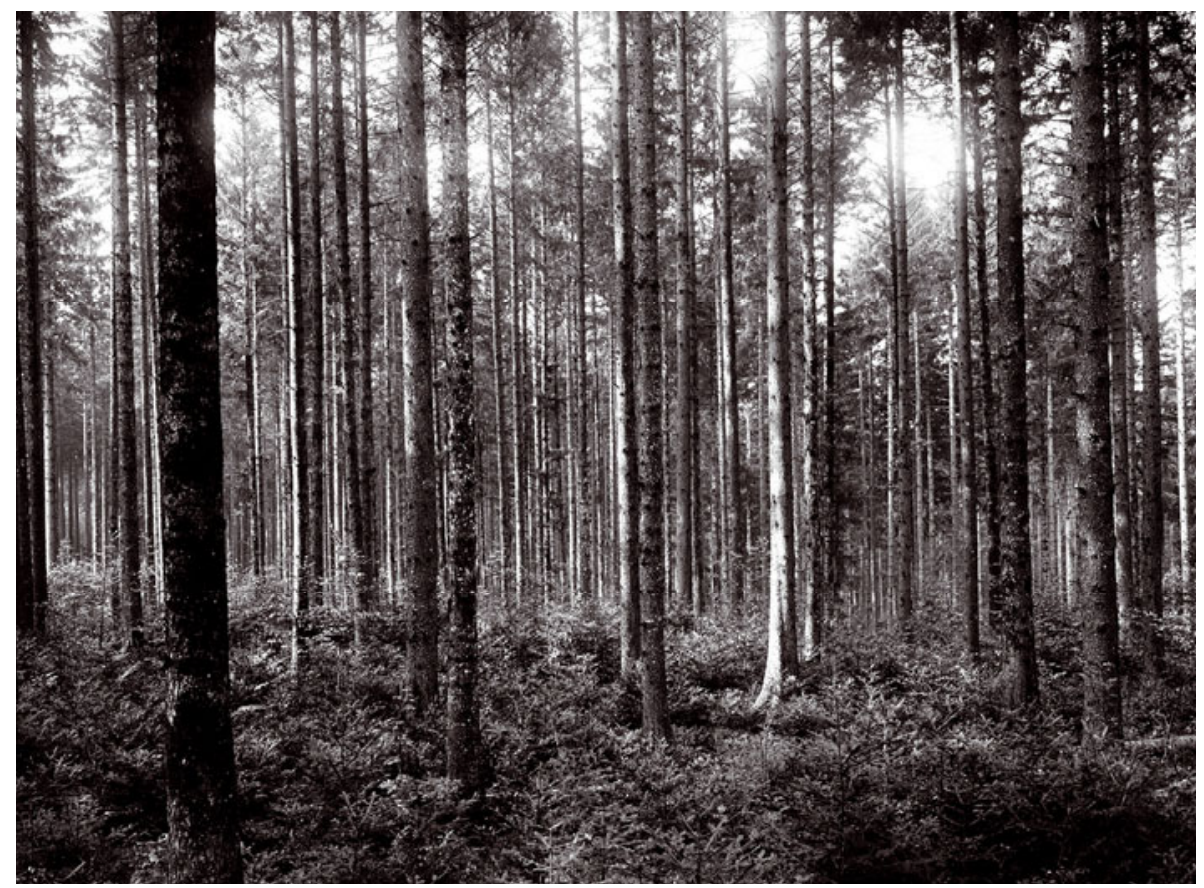

Figure 6. Photograph of a stand with a high yield level. Plot $21-052$, Biel, age 102 y, yield level $1.22, G=66.5 \mathrm{~m}^{2} / \mathrm{ha}$.

\section{CONCLUSION}

Up to now the yield tables and other growth models represent only full closed stands or regular opening of the canopy in the case of thinning regimes. In reality, as soon as canopy interruptions occur, such models are no longer reliable. Thus yield models are generally not appropriate for projecting stand development, or only under certain conditions. The difficulty is that such mortality events from disturbances are stochastic (Drössler and Lüpke, 2005; Quine and Bell, 1998; Schütz et al. 2006; Zeibig et al., 2005) and assessing the risk occurrence implies different methodological probabilistic from those used to estimate yield alone. For instance, it needs largely corresponding areas covering hundreds of hectares, way beyond the usual reference for yield plots. Furthermore, the risk of canopy dislocation varies with regional frequency of storms and with advancement of ageing factors. From research on comparable virgin forest, we know that the life cycle duration seems to present some constancy (Korpel, 1995), 250 y for beech between 300 and 350 for spruce. Within this time the stand will have been completely renewed. Nevertheless the inclusion of risk in growth models is an interesting prospect that requires more research.

Yield level has been interpreted as a potential for a horizontal space occupancy (Schmidt, 1973), as variable properties for competition (and for self-thinning) so that a stand can afford more (or fewer) stem numbers (Schütz, 2008). Pretzsch (2000) considers it as an expression of the site carrying capacity. A high yield level leads to intensified tightness (expressed as stem density, see Fig. 6), and thus to reductions in the individual increment. But the proportionally higher number of trees per area tends to enhance slightly the total increment (Schütz,
2008). The variations in the yield level have not yet been completely explained. It seems realistic to consider that they could have to do with the limitations of the site resources (water, nutrients). Some general dependencies with broad sites factors, such as precipitation and elevation, are discernable (Schütz, 2008), but these do not explain the whole variation. Other attempts to include edaphical orographical variables are interesting, but there is methodological problem with assessing accurately and representatively the site characteristics, particularly for edaphic variables (Bégin and Schütz, 1994; Schütz and Badoux, 1979). Wide variations in yield levels within short distances have been observed (Pretzsch, personal communication), even in the same communal location (Schütz, 1992). The fact that the yield level can be assessed correctly with the basal area $G$ is interesting and applicable for modelling purposes, but more research is needed to explain the relationship.

Acknowledgements: We thank colleague Milan Saniga, Professor of Silviculture at the Technical University Zvolen, Slovakia for providing data form the virgin forest plots on Slovakia and Silvia Dingwall for bringing the text closer to good English. We are also grateful to two anonymous reviewers for helpful comments on an earlier draft of this manuscript.

\section{REFERENCES}

Ammann P.L., 2004. Untersuchung der natürlichen Entwicklungsdynamik in Jungwaldbeständen: Biologische Rationalisierung der waldbaulichen Produktion bei Fichte, Esche, Bergahorn und Buche. Ph. D. thesis Nr. 15761, ETH, Zürich, 342 p.

Assmann E., 1957. Standraumregelung und Ertragsleistung, Forstarchiv 28: $217-223$. 
Assmann E., 1974. Zum Begriff "Ertragsniveau”. Forstwiss. Cent.bl. 93 : $177-179$.

Assmann E., 1995. Bedeutung des “erweiterten Eichhorn'schen Gesetzes" für die Konstruktion von Fichten Ertragstafeln. Forstwiss. Cent.bl. 74: 321-330.

Assmann E. and Franz F., 1963. Vorläufige Fichten-Ertragstafel für Bayern. Institut für Ertragskunde forstliche Forschungsanstalt München, München, $112 \mathrm{p}$.

Bachofen H. and Zingg A., 2001. Effectiveness of structure improvement thinning on stand structure in subalpine Norway spruce (Picea abies (L.) Karst.) stands. For. Ecol. Manage. 145: 137-149.

Bégin J. and Schütz J.P., 1994. Estimation of total yield of Douglas fir by means of incomplete growth series. Ann. Sci. For. 51: 345-355.

Bergel D., 1985. Schätzverfahren zur Bestimmung des Ertragsniveaus von Fichtenbeständen. Cent.bl. Gesamte Forstwes. 102: 86-96.

Bi H., 2001. The self-thinning surface. For. Sci. 47: 361-370.

Drössler L. and von Lüpke B., 2005. Canopy gaps in two virgin beech forest reserves in Slovakia. J. For. Sci. 51: 446-457.

Enquist B. and Niklas K.J., 2001. Invariant scaling relations across treedominated communities. Nature 40: 655-741.

Franz F., 1965. Ermittlung von Schätzwerten der natürlichen Grundfläche mit Hilfe ertragskundlicher Bestimmungsgrössen des verbleibenden Bestandes. Forstwiss. Cent.bl. 84: 357-386.

Franz F., 1967. Ertragsniveau-Schätzverfahren für die Fichte an Hand einmalig erhobener Bestandesgrössen. Forstwiss. Cent.bl. 86: 98-125.

Hamilton G.J. and Christie J.M., 1971. Forest management tables (metric). Forestry Commission Booklet No. 34. Her Majesty's Stationery Office, London, $201 \mathrm{p}$.

Hasenauer H., Burkhart H.E., and Sterba H., 1994. Variation in potential volume yield of loblolly pine plantations. For. Sci. 40: 162-176.

Keller W., 1978. Einfacher ertragskundlicher Bonitätschlüssel für Waldbestände in der Schweiz. Mitt. Eidg. Forsch. Anst. Wald Schnee Landsch. 54: 3-98.

Kennel R., 1973. Die Bestimmung des Ertragsniveaus bei der Buche, Forstwiss. Cent.bl. 92: 226-234.

Korpel Š., 1995. Die Urwälder der Westkarpaten. G. Fischer, Stuttgart, $310 \mathrm{p}$.

Kramer H., 1976. Zur Bestimmung des Ertragsniveaus als Grundlage einer Einheitsertragstafel. Forstarchiv 47: 158-162.

Langton C.G., 1989. Artificial life. In: C.G. Langton (Ed.), The proceedings of an interdisciplinary workshop on the synthesis and simulation of living systems, held sept. 1989 in Los Alamos, New Mexico. Santa Fe Institute studies in the science of complexity, Proceedings 6, Addison-Weseley, Redwoodcity, pp. 1-655.

Lonsdale W.M., 1990. The self-thinning rule: dead or alive. Ecology 71: $1373-1388$.

Morris C.E., 2003. How does fertility of the substrate affect intraspecific competition? Evidence and synthesis from self-thinning. Ecol. Res. 18: 287-305.

Pfadenhauer J., 1975. Bestimmungen zwischen Standortseinheiten, Klima, Stickstoffernährung und potentieller Wuchsleistung der Fichte im Bayerischen Flyschgebiet. Habil. Thesis, A.R. Gantner, Vaduz, Dissertationes Botanicae 30, 239 p.

Pretzsch H., 2000. Die Regeln von Reineke, Yoda und das Gesetz der räumlichen Allometrie. Allg. For. Jagdztg. 171: 205-210.

Pretzsch H., 2006. Species-specific allometric scaling under selfthinning: evidence from long-term plots in forest stands. Oecologia 146: $572-583$.
Pretzsch H., 2008. Wirkung von Stress auf die Allometrie von Baumkronen. In: Nagel G. (Ed.), Jahrestagung 2008, Trippstadt, 5.8. Mai 2008, Deutscher Verband Forstlicher Forschungsanstalten, Sektion Ertragskunde, Göttingen, pp. 5-21.

Pretzsch H. and Biber P., 2005. A Re-evaluation of Reineke's rule and stand density index. For. Sci. 51: 304-320.

Pretzsch H. and Schütze G., 2005. Crown allometry and growing space efficiency of Norway spruce (Picea abies [L.] Karst.) and European beech (Fagus sylvatica L.) in pure and mixed stands. Plant Biol. 7: 628-639.

Reineke L.H., 1933. Perfecting a stand density index for even-aged forests. J. Agric. Res. 46: 627-638.

Quine C.P. and Bell P.D., 1998. Monitoring of windthrow occurrence and progression in spruce forests in Britain. Forestry 71: 87-97.

Schädelin W., 1934. Die Durchforstung als Auslese- und Veredlungsbetrieb höchster Wertleistung. P. Haupt, Bern-Leipzig, $96 \mathrm{p}$.

Schmidt A., 1973. Ertragsniveau und Standort, dargestellt am Beispiel der Kiefer. Forstwiss. Cent.bl. 92: 268-274.

Schütz J.P., 1992. Ueberlegungen zum Problem des Ertragsniveaus, seine Bedeutung und praktische Erfassung. In: Kenk G. (Ed.), Jahrestagung 1992, Grillenburg, 1.-3. Juni 1992, Deutscher Verband Forstlicher Forschungsanstalten, Sektion Ertragskunde, Freiburg i. Br., pp. 1-14.

Schütz J.P., 2006. Funktionelle Bestandescharakterisierung: Die Fortschreibung der Stammzahlverteilungen, ein versprechender Weg zur Modellierung der Bestandesentwicklung. In: Nagel G. (Ed.), Jahrestagung 2006, Staufen, 29.-31. Mai 2006, Deutscher Verband Forstlicher Forschungsanstalten, Sektion Ertragskunde, Göttingen, pp. 54-63.

Schütz J.P., 2008. Ertragsniveau und maximale Bestockungsdichte als Grundlage für die Modellierung der natürlichen Mortalität. In: Nagel G. (Ed.), Jahrestagung 2008, Trippstadt, 5.-8. Mai 2008, Deutscher Verband Forstlicher Forschungsanstalten, Sektion Ertragskunde, Göttingen, pp. 123-132.

Schütz J.P. and Badoux E., 1979. Production de jeunes peuplements de chênes en relation avec la station. Mitt. Eidgenöss. Anst. Forstl. Vers. wes. 55: 5-141.

Schütz J.P., Götz M., Schmid W., and Mandallaz D., 2006. Vulnerability of spruce (Picea abies) and beech (Fagus sylvatica) forests stands to storms and consequences for silviculture. Eur. J. For. Res. 125: 291-302.

Schütz J.P. and Zingg A., 2008. Zuwachsprognose nach der sozialen Hierarchie im Entwicklungs- und Wuchsmodell SiWaWa. In: Nagel G. (Ed.), Jahrestagung 2007, Alsberg-Eudorf, 21.-23 Mai 2007, Deutscher Verband Forstlicher Forschungsanstalten, Sektion Ertragskunde, Göttingen, pp. 180-187.

Sterba H., 1981. Natürlicher Bestockungsgrad und Reineke's SDI. Cent.bl. Gesamte Forstwes. 98: 101-116.

Verein Deutscher Forstlicher Versuchsanstalten, 1902. Beratungen der vom Vereine Deutscher Forstlicher Versuchsanstalten eingesetzten Kommission zur Feststellung des neuen Arbeitsplanes für Durchforstung- und Lichtungsversuche. Allg. For. Jadgztg. 78: 180184.

Weller D.E., 1987. A reevaluation of the $-3 / 2$ power rule of plant selfthinning, Ecol. Monogr. 57: 23-43.

White J., 1981. The allometric interpretation of the self-thinning rule. J. Theor. Biol. 89: 475-500.

Yoda K., Kira T., Ogawa H., and Hozumi K., 1963. Thelf-thinning in overcrowded pure stands under cultivated and natural conditions: intraspecific competition among higher plants. Journal Institute Polytechnics Osaka city University, Series D, 14: 107-129. 
Zhang L., Bi H., Grove J.H., and Heath L.S., 2005. A comparison of alternative methods for estimating the self-thinning boundary line. Can. J. For. Res. 35: 1507-1514

Zeibig A., Diaci J., and Wagner S., 2005. Gap disturbance patterns of a Fagus sylvatica virgin forest remnant in the mountain vegetation belt of Slovenia. For. Snow. Landsc. Res. 79: 69-80.

Zeide B., 1985. Tolerance and self-tolerance of trees. For. Ecol. Manage. 13: $149-166$.
Zeide B., 1987. Analysis of the $3 / 2$ power law of self-thinning. For. Sci. 33: 517-537.

Zeide B., 2005. How to measure stand density. Trees 19: 1-14.

Zingg A., 1996. Diameter and Basal Area Increment in Permanent Growth and Yield Plots in Switzerland. In: Spiecker H., Mielikäinen K., Köhl M., and Skovsgaard J.P. (Eds.), Growth Trends in European Forests, European Forest Institute Research Report No. 5, Berlin \& Heidelberg, Springer, pp. 239-265. 